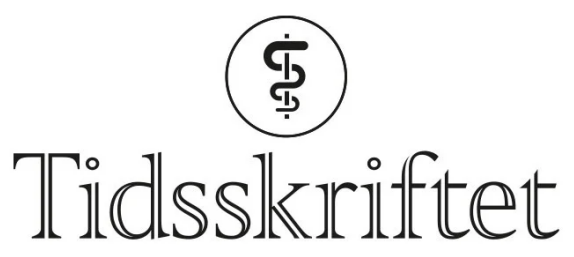

DEN NORSKE LEGEFORENING

\title{
Koronapandemien - erfaringer fra et mikrobiologisk laboratorium
}

KRONIKK

\section{ELISABETH TOVERUD LANDAAS}

eltlan@ous-hf.no

Elisabeth Toverud Landaas er spesialist i medisinsk mikrobiologi, overlege ved Avdeling for mikrobiologi, Oslo universitetssykehus og førsteamanuensis ved Universitetet i Oslo.

Forfatteren har fylt ut ICMJE-skjemaet og oppgir ingen interessekonflikter.

\section{ARNE MICHAEL TAXT}

Arne Michael Taxt er spesialist i medisinsk mikrobiologi og i barnesykdommer og er ansatt i bistilling ved Avdeling for mikrobiologi, Oslo universitetssykehus. Han har ph.d. i vaksineutvikling. Forfatteren har fylt ut ICMJE-skjemaet og oppgir ingen interessekonflikter.

\section{ANDREAS LIND}

Andreas Lind er spesialist i indremedisin, i infeksjonssykdommer og i medisinsk mikrobiologi. Han er overlege og enhetsleder ved Avdeling for mikrobiologi, er ansvarlig for virusdiagnostikk ved Oslo universitetssykehus, Ullevål, inkludert SARS-CoV-2-analysene, og har ph.d. i immunresponser ved terapeutisk hivvaksinering.

Forfatteren har fylt ut ICMJE-skjemaet og oppgir ingen interessekonflikter.

\section{FREDRIK MÜLLER}

Fredrik Müller er spesialist i medisinsk mikrobiologi, avdelingsleder ved Avdeling for mikrobiologi, Oslo universitetssykehus og professor ved Universitetet i Oslo.

Forfatteren har fylt ut ICMJE-skjemaet og oppgir ingen interessekonflikter.

\section{Siden starten av pandemien har Avdeling for mikrobiologi ved Oslo universitetssykehus utført nesten 1,6 millioner analyser for påvisning av SARS-CoV-2. Hva har vi lært, og hva kan gjøres for at vi skal være bedre rustet for neste pandemi?}

I Norge ble det første tilfellet av severe acute respiratory syndrome coronavirus 2 (SARS-CoV-2) påvist 26. februar 2020. Siden har testing vært en svært sentral del av strategien for å kontrollere pandemien, og i skrivende stund har over 195 ooo smittetilfeller blitt påvist. Analysene har i stor grad blitt utført ved landets mikrobiologiske laboratorier. Hvordan har vi arbeidet i laboratoriet under pandemien? Og hvilke erfaringer må vi ta med oss for å være bedre forberedt til neste pandemi?

\section{Virusdiagnostikk}


Den dominerende metoden for viruspåvisning er polymerasekjedereaksjon (PCR), en svært sensitiv metode for å undersøke om spesifikke gensekvenser er til stede i en prøve. Ved behov for en ny analyse kan man enten utvikle en egenprodusert PCR-test eller benytte kommersielle tester, hvis disse er tilgjengelige.

For etablering av en egenprodusert test brukes informasjon fra gendatabaser og eventuelle tidligere publiserte protokoller til å finne gensekvenser som er spesifikke for det viruset man ønsker å påvise. Reagenser bestilles enkeltvis fra ulike leverandører og er rimelige i innkjøp. Før testen tas i bruk gjøres en grundig utprøving og validering ved å undersøke et større antall kjente prøver. Slik metodeutvikling er omfattende og fordrer personell med høy molekylærbiologisk kompetanse.

\section{«Denne kapasiteten måtte bygges opp fra grunnen av, da det ikke forelå noen beredskapsplaner for å etablere slik storvolumdiagnostikk»}

For å ta i bruk kommersielle tester kreves en mindre omfattende kvalitetssjekk, da mye allerede er gjort fra produsentens side. De kommersielle testene har oftest høy kvalitet og kapasitet, men prisen per test og for utstyr er betydelig høyere enn for egenproduserte tester. Gensekvensen som testen undersøker for, er ikke tilgjengelig, hvilket vanskeliggjør arbeidet for laboratoriene ved feilsøking og uventede resultater. Det er heller ikke mulig for laboratoriet å tilpasse testene til nye virusvarianter. Testreagenser og teknisk utstyr må ofte kjøpes fra samme produsent, noe som gir lite fleksibilitet ved leveranseproblemer.

\section{De første koronaanalysene}

I løpet av januar 2020 ble SARS-CoV-2 sekvensert av kinesiske forskere, og 12. januar 2020 ble gensekvensen delt med Verdens helseorganisasjon (WHO) (1) ramme 1). Få dager senere ble protokollen for en kvalitetssikret PCR-test gjort tilgjengelig (Berlin-protokollen) (( $\underline{2})$. Referanselaboratoriet ved Folkehelseinstituttet (FHI) fikk denne metoden raskt på plass og var klar til å utføre de første testene 24. januar (3), men av kapasitetshensyn ble det tidlig klart at også landets mikrobiologiske sykehuslaboratorier måtte etablere koronadiagnostikk.

\section{Ramme 1 Hendelser og milepæler under koronapandemien}

12.1.202O: SARS-CoV-2 s gensekvens blir delt med WHO

13.1.2020: Første PCR-protokoll (Berlin-protokollen) blir publisert

24.1.2020: PCR-test blir tilgjengelig på Folkehelseinstituttet

30.1.2020: WHO erklærer internasjonal folkehelsekrise

19.2.2020: PCR-test blir tilgjengelig på Oslo universitetssykehus

26.2.2020: Første SARS-CoV-2-tilfelle i Norge blir påvist ved Oslo universitetssykehus

12.3.2020: Nedstengningen av Norge starter

17.6.2020: Storvolumdiagnostikk settes i gang ved Oslo universitetssykehus

27.12.2020: Første vaksinedose i Norge blir satt

4.1.2021: Alfavarianten blir påvist i Norge

1.2.2021: Helgenomsekvensering av prøver settes i gang ved Oslo universitetssykehus

15.4.2021: Deltavarianten blir påvist i Norge

23.4.2021: Én million prøver er blitt analysert ved Oslo universitetssykehus 
Ved Avdeling for mikrobiologi ved Oslo universitetssykehus begynte arbeidet med å etablere en egenprodusert PCR-test basert på Berlin-protokollen 2o. januar. Omfattende uttestinger viste at metoden fungerte godt, og fra 19. februar kunne vi tilby SARS-CoV-2-PCR som del av rutinediagnostikken. Allerede én uke senere påviste vi det første tilfellet av viruset i Norge.

På grunn av manuelle rutiner var testkapasiteten i starten svært begrenset. Det var derfor en milepæl da den første kommersielle og automatiserte SARS-CoV-2-PCR-testen ble tilgjengelig (Cobas® 680o System fra Roche). Denne tok vi i bruk 23. mars med en kapasitet på rundt 1200 analyser i døgnet. Imidlertid oppstod det raskt global mangel på reagenser og forbruksartikler, slik at vi på langt nær fikk utnyttet instrumentets fulle kapasitet.

\section{Kraftig opptrapping av testkapasiteten}

Grunnet begrenset kapasitet både ved teststasjonene, i laboratoriene og ved smitteoppsporing i kommunene var det i de første månedene av pandemien strenge kriterier for hvem som kunne testes. Behovet for rask oppskalering av kapasiteten var prekært. Oslo universitetssykehus fikk 2. april 2020 i oppdrag av Helse Sør- $\emptyset$ st å bygge opp et storvolumlaboratorium for påvisning av SARS-CoV-2 med kapasitet på inntil 15000 analyser/døgn. Dette skulle betjene rekvirentene i Oslo, men også avlaste laboratorier i Viken, Agder samt Vestfold og Telemark.

\section{"Vi har mange ganger stått i fare for å gå tom for slikt utstyr, og mye tid har gått med til å kontakte leverandører rundt om i verden»}

Denne kapasiteten måtte bygges opp fra grunnen av, da det ikke forelå noen beredskapsplaner for å etablere slik storvolumdiagnostikk. Dette innebar et omfattende arbeid for raskt å få tilgang til areal fra andre avdelinger, ombygging av lokaler, anskaffelse av nytt utstyr, lån av personell fra andre avdelinger samt nyansettelser og utvidelse av åpningstidene. Videre måtte en effektiv prøvelogistikk på plass, og ulike IKT-utfordringer måtte løses, spesielt opprettelse av elektroniske rekvireringsløsninger og systemer for effektiv svarformidling.

Bruk av magnetkuler og reagenser produsert ved NTNU for RNA-ekstraksjon var sentralt for å lykkes med storskaladiagnostikken. Magnetkulene kunne leveres i stort omfang, og med en slik egenprodusert metode ble vi mindre avhengige av reagenser fra kommersielle aktører. Validering og iverksettelse av metoden, som innebar utstrakt bruk av nye pipetteringsroboter, krevde stor innsats både fra spesialisert personell ved vår utviklingsseksjon og fra leverandørene. Storskalalaboratoriet ble satt i drift i juni 2020, med høy analysekapasitet og kortere svartid som resultat. Selv om vi var mindre avhengige av reagenser fra kommersielle aktører, oppsto det krevende leveranseproblemer, da det viste seg å være begrenset global tilgang på forbruksutstyr som pipettespisser, PCR-brett og pinsetter. Vi har mange ganger stått i fare for å gå tom for slikt utstyr, og mye tid har gått med til å kontakte leverandører rundt om i verden.

\section{Elektronisk rekvirering og varsling}

Før pandemien var elektronisk rekvirering av våre analyser som hovedregel ikke mulig for rekvirenter utenfor sykehuset, men i pandemisituasjonen ble bruk av papirrekvisisjoner uhåndterbart. Takket være god innsats fra vår IKT-leverandør Sykehuspartner, ble elektronisk rekvirering av koronaprøver til storvolumlaboratoriet fra teststasjonene etablert. Dette var avgjørende for en sikker og effektiv håndtering av det store prøvevolumet. 
Vanligvis er det kun rekvirenten som mottar prøvesvar, men i en pandemisituasjon trenger både pasienten selv og teststasjonene prøvesvar formidlet raskt og effektivt. I tillegg skal påvisning av SARS-CoV-2 meldes Folkehelseinstituttet samt varsles smittevernoverlege i kommunen i henhold til forskrift om Meldingssystem for smittsomme sykdommer (4). Dette danner grunnlaget for smittesporingsarbeidet som kommunene utfører. Før pandemien ble meldepliktige sykdommer i stor grad meldt på papir og varslet per telefon. For SARS-CoV-2 førte dette for alle involverte parter til et betydelig merarbeid som raskt ble uhåndterbart og som forsinket smittesporingen. For å ivareta telefonisk varsling av opp mot 100 prøvesvar med personalia per dag våren 2020 måtte avdelingen opprette et nytt ekstra vaktlag på kveldstid og i helgene.

Etter hvert ble det opprettet en nasjonal, elektronisk database ved Folkehelseinstituttet som mottar alle positive SARS-CoV-2-PCR-svar og videreformidler disse til helsenorge.no. Det er imidlertid så langt ikke etablert noen nasjonal løsning for elektronisk varsling av prøvesvar til smittevernoverlegene i kommunene. Takket være godt samarbeid med Oslo kommune (Helseetaten) ble det opprettet elektronisk varsling fra vår avdeling til Oslo kommunes smittesporere, noe som bedret situasjonen betraktelig. Likevel er det fremdeles en betydelig jobb å varsle smittevernoverleger i andre kommuner per telefon, og for de fleste laboratorier i landet er dette den eneste tilgjengelige løsningen.

\section{Ny virusdiagnostikk}

Allerede våren 2020 merket klinikere og myndigheter behov for flere typer undersøkelser for SARS-CoV-2, og arbeidet med disse krevde også en betydelig innsats. Påvisning av viruset i andre prøvematerialer enn luftveisprøver var ønsket, og undersøkelse av spytt, blod, spinalvæske, feces og vevsprøver ble validert, likeledes kvantitering av virusmengde i blod og luftveisprøver. Antigen- og PCR-hurtigtester ble også testet ut da de kom på markedet. Da kommersielle antistofftester ble tilgjengelige, ble det etablert et stort panel av serumprøver tatt før pandemien og på ulike tidspunkt etter SARS-CoV-2-sykdom, og det ble nedlagt et omfattende arbeid med sammenlikning av tester fra flere produsenter $\mathrm{i}$ samarbeid med Avdeling for immunologi og transfusjonsmedisin, som etablerte egenproduserte tester.

\section{«EU-regulativet er en trussel mot laboratorienes muligheter til å sette opp egenproduserte tester i årene fremover»}

Mutasjoner i SARS-CoV-2 har gitt opphav til en rekke virusvarianter, hvorav noen med $ø \mathrm{kt}$ virulens og/eller smittsomhet. Variantovervåkning har derfor vært viktig, og gullstandard for dette er helgenomsekvensering, som ble etablert i samarbeid med Avdeling for medisinsk genetikk ved Oslo universitetssykehus. Per 13. oktober $2021 \mathrm{er} \mathrm{ca.} 20$ ooo av våre prøver sekvensert. For raskere å kunne gi svar på mulige virusvarianter har vi i tillegg etablert egenproduserte PCR-tester basert på publiserte protokoller; for alfa-, beta- og gammavariantene i begynnelsen av 2021 (5) og for deltavarianten i mai 2021.

\section{Rolle i pandemiberedskapen}

Myndighetene presenterte i slutten av 2019 en nasjonal beredskapsplan mot utbrudd av alvorlige, smittsomme sykdommer (므). Beredskapsplanen omtaler ikke oppbygging av storvolumdiagnostikk og har ellers kun en kortfattet beskrivelse av sykehuslaboratorienes rolle under en pandemi. Beredskapsplanen angir at «mikrobiologiske laboratorier ved universitetssykehusene skal ta initiativ til å etablere samarbeidsavtaler med andre laboratorier om kvalitativ og kvantitativ beredskap innen sine regioner». Dette ble ivaretatt av Helse $ऽ ø r-\emptyset$ st, som koordinerte koronadiagnostikken i helseregionen og nasjonalt. 
Arbeidet med SARS-CoV-2-PCR i vår avdeling var på eget initiativ, og det kom ikke klare forespørsler om dette verken fra Oslo universitetssykehus eller Folkehelseinstituttet i løpet av januar eller begynnelsen av februar 2020. Det fremsto som uklart hvorvidt Folkehelseinstituttet hadde myndighet til å kontrollere sykehuslaboratorienes diagnostikk, og det var i starten ikke klare kommunikasjonslinjer mellom laboratoriene og sentrale helsemyndigheter.

Da Helse Sør-Øst ga oss i oppdrag å etablere et storvolumlaboratorium, måtte både personell og lokaler lånes fra andre avdelinger. Dette understreker hvordan dagens tendens til å bygge for små sykehus, inkludert laboratorier, påvirker mulighetene for å kunne utvide kapasiteten i en beredskapssituasjon og ha tilstrekkelig areal for å arbeide i henhold til gode smittevernrutiner.

Før pandemien var det betydelige mangler knyttet til IKT-systemer for håndtering av rekvisisjoner, prøvesvar og varsling av funn. En del av dette er kommet på plass underveis, men det kunne og burde ha vært etablert i forkant. En nasjonal løsning for elektronisk varsling til smittevernleger i kommunene er fortsatt ikke etablert, selv om dette har vært etterspurt siden pandemiens begynnelse.

\section{Egenprodusert diagnostikk}

De første analyseoppsettene for SARS-CoV-2 i laboratoriene var egenproduserte metoder. Da vi i mars 2020 fikk etablert en kommersiell test med høy kapasitet, viste det seg at tilgangen på reagenser og forbruksmateriell var utilstrekkelig - et problem som har vedvart. Bruken av egenproduserte metoder har dermed spilt en sentral rolle i håndteringen av pandemien i Norge som ledd i myndighetenes strategi for testing, isolasjon, smittesporing og karantene (TISK). Å sette opp slike tester krever kompetanse og erfaring. For å kunne opprettholde evnen til raskt å etablere nye metoder er det svært viktig at laboratoriene vedlikeholder og viderefører denne kompetansen.

«For å kunne møte neste pandemi er det helt essensielt å opprettholde kompetansen til å etablere egenproduserte analysemetoder»

Det nye in vitro-diagnostikkregulativet fra EU angir blant annet regler for CE-merking og godkjenning av kommersielle og egenproduserte analyser til bruk i diagnostikk (7.). Regulativet trer i kraft i Norge etter en overgangsperiode i mai 2022, men EU-kommisjonen har nettopp foreslått nye overgangsregler. Reglene for CE-merking er svært omfattende, og regulativet er dermed en trussel mot laboratorienes muligheter til å sette opp egenproduserte tester i årene fremover. Slik sett utfordrer regulativet vår beredskap ved kommende pandemier. Også internasjonalt har det blitt påpekt hvor kritisk svekket SARS$\mathrm{CoV}$-2-diagnostikken hadde vært hvis regulativet hadde vært gjeldende under denne pandemien ( $\underline{8})$.

\section{Er vi rustet for neste pandemi?}

For å kunne møte neste pandemi er det helt essensielt å opprettholde kompetansen til å etablere egenproduserte analysemetoder. Vi trenger også en diagnostisk beredskap som omfatter areal og instrumentering, slik at analysekapasiteten i landet raskt kan skaleres opp til en størrelsesorden på $5 \%$ av befolkningen per uke, slik kravet har vært under denne pandemien. Videre trengs det forbedringer av dagens IKT-løsninger, inklusive elektronisk rekvirering og svar innen og på tvers av primærhelsetjenesten og spesialisthelsetjenesten. Opprettelse av et elektronisk varslingssystem til kommunene bør være høyt prioritert. Det bør også implementering av nasjonale systemer for håndtering av hjelpenummer og opprettelse av en nasjonal database for deling av sekvensdata. Beredskapsplaner for 
lagerhold av reagenser, diagnostisk utstyr og smittevernutstyr må gjennomgås, og nasjonal produksjon bør vurderes. Laboratorienes rolle og diagnostiske kapasitet må avklares og innarbeides i gjeldende pandemiplaner.

\section{LITTERATUR}

1. World Health Organization. Novel Coronavirus (2019-nCoV) Situation report 1. 21 January 2020. https://www.who.int/docs/default-source/coronaviruse/situation-reports/20200121-sitrep-1-2019ncov.pdf?sfvrsn=20a99c10_4 Lest 2.11.2021.

2. Corman VM, Landt O, Kaiser M et al. Detection of 2019 novel coronavirus (2019-nCoV) by real-time RT-PCR. Euro Surveill 2020; 25: 2000045. [PubMed][CrossRef]

3. NOU 2021: 6. Myndighetenes håndtering av koronapandemien - Rapport fra Koronakommisjonen. https://www.regjeringen.no/no/dokumenter/nou-2021-6/id2844388/ Lest 2.11.2021.

4. FOR-2003-06-20-740. Forskrift om Meldingssystem for smittsomme sykdommer (MSIS-forskriften). https://lovdata.no/dokument/SF/forskrift/2003-06-20-740\#KAPITTEL_32003 Lest 2.11.2021.

5. Lind A, Barlinn R, Landaas ET et al. Rapid SARS-CoV-2 variant monitoring using PCR confirmed by whole genome sequencing in a high-volume diagnostic laboratory. J Clin Virol 2021;141: 104906. [PubMed][CrossRef]

6. Nasjonal beredskapsplan mot utbrudd av alvorlige smittsomme sykdommer. https://www.regjeringen.no/no/dokumenter/nasjonal-beredskapsplan-mot-utbrudd-av-alvorligesmittsomme-sykdommer/id2680654/2019 Lest 2.11.2021.

7. The European Union In Vitro Diagnostics Regulation. https://euivdr.com/ Lest 2.11.2021.

8. Vermeersch P, André E. How the European in vitro diagnostic regulation could negatively impact the European response to the next pandemic: an urgent call for action before May 2022. Clin Microbiol Infect 2021; 27: 1074-5. [PubMed][CrossRef]

Publisert: 12. november 2021. Tidsskr Nor Legeforen. DOI: 10.4045/tidsskr.21.0643

Mottatt 9.9.2021, første revisjon innsendt 13.10.2021, godkjent 2.11.2021.

(C) Tidsskrift for Den norske legeforening 2023. Lastet ned fra tidsskriftet.no 26. april 2023. 